\title{
Economic analysis of Intellectual Property: Thoughts on the Ecuadorian case
}

\author{
Análisis económico de la propiedad intelectual: \\ consideraciones del Caso Ecuatoriano
}

Angel Fabián Albán de Saá: Head of litigation at Meythaler \& Zambrano Lawyers

City: Quito

Country: Ecuador

Mary Mar Samaniego Alcívar: Deputy Head of Criminal Department at Meythaler \& Zambrano Lawyers

City: Quito

Pais: Ecuador

Original article (research)

RFJ, No 8, 2020, pp. 197-221, ISSN 2588-0837

RESUMEN: El Análisis Económico del Derecho de la Propiedad Intelectual permite comprender de mejor manera, la preferencia a la generación de un ordenamiento jurídico que proteja los derechos de propiedad intelectual, coma una forma de generar incentivos sociales más eficientes para promover su creación por cuanto permitirá al creador recuperar los costos incurridos y obtener los beneficios esperados.

PALABRAS CLAVE: derechos de autor, norma jurídica, monopolio, creación, derecho económico.

ABSTRACT: The Economic Analysis of Intellectual Property Law allows us to understand better the importance of generating a legal system that protects intellectual property rights and generates more efficient social incentives and promote creation. Social incentives will allow creators to recover the costs incurred and obtain the expected benefits. 
KEYWORDS: copyright, legal standard, monopoly, creation, economic law.

\section{INTRODUCTION}

Property and the right to own it began their history from the earliest times where man sought to deny the use of what was "his" to other men. Then, the cost of obtaining and appropriating goods was the use of force.

Therefore, property law has its origin in the most in-depth part of human evolution. Unfortunately, there is no certainty about the precise way and time in which man created the concept of property right. The only certainty now is that all countries, regardless of their ideological tendency, maintain different forms of property: public, private, mixed, intellectual, collective, among others.

Undoubtedly, people's right to property has become one of the most helpful methods for social development since it is regulated in different trends depending even on people's beliefs. There will be those societies where only men have the right to property, not women. Moreover, let us not forget that property rights were applied to men before the 1800s. Without getting into greater detail, the concept of property rights itself allows to extract the component elements of it:

1. Real Academia Española (2014) defines property as the "right or faculty to own something and to be able to dispose of it within legal limits; something that is subject to the domain, especially if it is real estate or root."

It defines industrial property as the "exclusive exploitation right over trade names, trademarks, and patents, which the law recognizes for a certain period" (Real Academia Española, 2014); and intellectual property as the "right of exclusive exploitation over literary or artistic works, which the law recognizes to the author for a specified period." (Real Academia Española, 2014). 
2. The law understands property as "domain", and it defines it as a "real right in a tangible thing, to enjoy and dispose of it arbitrarily, not being against the law or the rights of others. The territory that is under the domination of a State or a sovereign." (Civil Code Ecuador, 2005, art. 599)

3. In economics, it is good that capital is being used for production.

The following elements can be obtained from these definitions, using the microeconomics simplification tool of the economic analysis of law:

1. The property requires the existence of a natural or legal person who will be referred to as owner;

2. It also needs the existence of a good that can be real, movable, immovable, informational, intellectual, or of any other kind;

3. The link between the first and the second element is the intention of keeping the property under their control. It refers to the relation of possession between the owner and the property;

4. In order to guarantee, encourage, recognize and protect the property, an organization is responsible for registering or providing protection to the property (it is usually the State); and,

5. As it will be argued in this paper, an essential element to define property is the cost-benefit analysis. Although it is not incorporated in property definitions, it is studied by economics and allows to understand the rationale for protecting property by the creation of "property rights.

These elements make it possible to observe natural or legal people can own that property. That there are different types of property. That a property enables owners to fulfil their condition of belonging, it is essential to obtain a benefit, "the cost", and to be protected by a standard and an entity.

When it comes to ownership of real assets, it can be easily proven, rivalled or excluded when their owner shows his possession with the respective property registry or mercantile 
inscription. However, to prove ownership of dematerialized goods is not an easy task due to the inherent high cost of obtaining, protecting, and recognizing their property.

As goods are less tangible, costs to create, protect, delimit, and to incentivize obtaining and generating property are higher. Therefore, it is necessary to look for different forms for protecting this less material property. Owners will not have incentives to maintain it, invest in it, and to enjoy it without protective measures in place.

The legal analysis of the property is valid, but combining it with economics strengthens it and can produce deductions closer to reality. Such findings will allow us to understand the reason why public policies prefer the protection of intellectual property.

In this context, the economic analysis of law, as a trend that combines law with economics, seeks to understand and predict the effects and consequences that a norm has on subjects' behaviour (Posner, 1998). In Law, legislators elaborate norms considering that they will have specific effects on people's conduct, but in reality, they may have different ones. As it is logical, legislators on their own cannot visualize all possible responses.

Economics gets ahead of individuals' behaviours, therefore, applying it with legal sciences generate different alternatives of understanding all possible people's attitudes facing a particular legal situation or norm.

The economic analysis of law is based on a welfare economy, "must be" decisions. It determines how a norm should be formulated based on a cost-benefit analysis, mainly considering:

1. People whose well-being is relevant to decision-making in the present.

2. (Bentham, 1993). Then, the well-being of each individual must be added to obtain the expected social benefit. (Duarte \& Jimenez, 2007) 
3. The search for an equitable distribution of resources (cost), therefore, the economic analysis of law is a social science that seeks to resolve the dilemma of applying norms based on the effects it will have. It proposes all behavioural alternatives for the people destined to respect or apply the norm. The study of the influence of a norm on people's behaviours requires considering the following microeconomics rules:

a. Rationality:People subject tolegal norms behave rationally according to their perspectives, criteria, interests, and preferences, not erratic, arbitrary, or servile.

b. Consequentialism. - For anticipating the possible consequences that the rules may have on the behaviour of the people subject to them.

c. Simplification. - the analysis is reduced to the most relevant factors of the events.

d. Contrast. - in order to know the operation of the legal norm in reality. For determining the effects of the rule, a period must be considered from its issuance to analyze the effects of the rule. (Coase, 1960, cited by Beyer, 1992)

This research paper aims to analyze the economic and legal arguments for intellectual property protection through the so-called property right. It also focuses on intangible goods incorporated within the intellectual property in order to explain why it is preferable to protect property rights. Finally, it proposes using market distortion techniques - monopolies - as an efficient method to generate incentives for creating, regulating and protecting less tangible property.

\section{PROPERTY AND PROPERTY RIGHTS IN ECUADOR}

Ecuador has already covered property rights by developing regulations for their protection. Consequently, the necessary cost for creating property rights has been assumed, which reduces transaction costs on possible disputes over property rights as established by the Coase Theorem. (Coase, 1960, cited by Beyer, 1992) 
As the State of Law, the Constitution of the Republic of Ecuador (2008) recognizes several types and forms of property. Its Chapter Six - Rights to Liberty, article 66, numeral 26 expresses: "People are recognized and guaranteed: (...) 26. The right to property in all its forms, with social and environmental function and responsibility. The right to access the property will become effective with the adoption of public policies, among other measures." (CRE, 2008). The Constitution also recognizes a Public Registry of Property in its article 265: "The public system of property registration will be administered concurrently between the Executive and the municipalities" (CRE, 2008). Therefore, excluding any form of private registry of property. (CRE, 2008)

Being the State the legal person in charge of recognizing and ensuring society's rights, it is clear that its primary obligation must be applying welfare economics while carrying out its activities and making decisions. The Article 321 of the Constitution supports it by stating that "The State recognizes and guarantees the right to property in its public, private, community, state, associative, cooperative, mixed forms, and that it must fulfil its social and environmental function.". (CRE, 2008) (Emphasis out of text)

Thus, the constitutional principles necessary for the creation and protection of property already exist and are recognized in Ecuadorian legislation since the Civil Code. For many, the Civil Code includes concepts that are applied at various stages of society, and that includes, not only rules that regulate the private sector, but also, standards of conduct that must be observed by society and regulated by the public sector. This Code also contains several provisions that regulate property.

The article 599 of the Civil Code defines domain -ownership- as: “(...) the real right in a tangible thing, to enjoy and dispose of it, by the provisions of the law and respecting the rights of others, whether individual or social (...)" (Civil Code Ecuador, 2005). The article 600 recognizes ownership on intangible things by saying that: "There is also a kind of 
property over incorporeal things. The usufructuary has his right of usufruct." (Civil Code Ecuador, 2005)

The text of the transcribed norm is clear. It leaves no doubt that it came from some great jurists' extended analysis. They did not only create concepts using intellectual exercise. They had valuable reasons. Nevertheless, what were these? What did encourage the legislator to divide public property from private, from real to intellectual property?

When the economic analysis of law is included in these premises, it is possible to understand and answer these questions. It is possible to understand many of the reasons why the property has protection and its classification. For example, the economic analysis of law can explain when a property is public or private based on the so-called "tragedy of the commons". (Heller \& Eisenberg, 1998) ${ }^{1}$

The idea of dividing public from private property was born when biologists tried to theorize the extinction of species. They asked themselves about what occurs when there are exploitation and excessive consumption of plant or animal species (goods, property), without there being control over it (protection). (Lloyd, 1833)

Then, the anti-commons problem considered that exclusive goods (private property) allow incorporating the criterion of time (cost) and the future consequences of actions on the ownership of goods (benefits). In other words, exclusive assets allow their owner to internalize the future benefits of investments made in work, capital, and opportunity costs (guarantee ownership), which does not happen when there is no exclusivity on goods.

1 The term "anti-commons tragedy" was coined in 1998 in a Harvard's Law Review article written by Michael Heller, a professor at Columbia Law School. In a same-year Science article, Heller, along with Rebecca Eisenberg, argued that biomedical research was one of several critical areas in which patent competition could prevent innovation and prevent better products from ending up on the market. Proponents of this theory suggest that too many property rights can backfire and reduce innovation. 
On the contrary, if there is a property that belongs to everyone, there are fewer incentives to own and exploit it individually or jointly. The individual benefit (for instance, the rent) will be so low that no one will want to invest in its exploitation. Even though the operating costs may be lower, the supply of the goods will be so high that the sale prices would not be enough to cover the operating costs. Overall, non-exclusive goods destroy resources (extinction), due to over-exploitation, and even, less production than desired.

In other words, if there is only one owner (i) or the exploitation of the property is regulated by the State (ii), the owner or the State will determine the limits of exploitation, since they receive all the benefits and assume all the costs, trying to adopt the optimal level of production.

The right to property has costs which must be analyzed in order to get clarity to defend, protect, use, and ultimately decide whether or not to own property. It can be concluded that property can only be had when the benefit obtained is higher than the cost of doing it; or when the benefit of protecting it is greater than the benefit of not protecting it.

In this case, it can be concluded that when a property belongs to all, there will be no incentives to produce or exploit it. Therefore, the ownership of property should belong to the State (Tétrel, 2006). As could be observed with this brief example, the economic analysis of law helped to identify the reasons why there can be private and public goods (private property and public property).

\section{ECONOMIC ANALYSIS OF PROPERTY IN ECUADOR}

Although this document will develop the concepts and definitions of intellectual property, it will take several elements of the concept of "property" to explain it in its application in the Ecuadorian scenario based on the economic analysis of law.

To explain the concept of "property", the economic analysis of law analyzes the costs of creation and protection (i), transaction costs (ii), and exclusion costs (iii). 
Firstly, the economic analysis of property must consider the costs of creating and protecting property regulations, which will include the costs of forecasting and creating the rule (i), the costs of identifying and detaining violators (ii), and the costs of sanctioning them (iii).

These costs in Ecuador have been incurred because there are already widely developed regulations in the Ecuadorian legal system (Civil Code, Property Registry Law, Commercial Registry Law, Ingenious Code).

The costs described above are part of the economic analysis of property rights, and in several cases, they explain the benefits that different conceptions of goods have:

a. In the event of substitute goods (Cortés, 1973) different goods can provide the same effect (two types of cars) that occurs when there are many manufacturers or providers (creation cost) of the same or similar good or service. The competition is attractive since producers will compete for price, quality, benefits, which will cause a social benefit.

The Constitution of the Republic of Ecuador establishes as an obligation of the State, to promote a competitive market, privileging it against monopoly and unfair competition. However, when they are public goods or when their creation or exploitation do not generate necessary incentives for individual production, the State is also allowed to control the market, creating public companies, regulating prices, and generating legal monopolies. Its article 335 expresses:

The State will regulate, control and intervene, when necessary, in economic exchanges and transactions; and it will sanction the exploitation, usury, hoarding, simulation, speculative intermediation of goods and services, as well as all forms of damage to economic rights and public and collective goods. The State will define a price policy aimed at protecting national production, will establish sanction mechanisms to avoid any practice of private monopoly and oligopoly or abuse of a dominant 
position in the market and other practices of unfair competition. (CRE, 2008) (Emphasis out of text)

b. In the case of complementary goods (North Holland, 1989) some goods can only be manufactured by one producer (for instance, apps for a type of computer). It means that the quantity supplied is less than the optimal quantity of production; there are higher production costs and lower social well-being.

In this case, competition is eliminated since it is a non-competitive market. It is causing little or overproduction thereof that will not allow optimal production to be generated. The most efficient market structure is the monopoly since it will allow the price to be lower, the quantity higher, and the social welfare greater.

A monopoly is a form of market distortion. Nevertheless, it must be used in this scenario because it generates significantly higher social benefit. Generally, monopolies are recommended when there are not sufficient incentives to produce goods or services in a particular way. In this sense, article 28 of the Organic Law of Regulation and Control of Market Power (2011) allows the development of non-competitive forms:

The establishment of restrictions on competition will be admissible by reasoned resolution of the Regulatory Board, for reasons of public interest, in any sector of the national economy, in the following cases:

1. For the development of a state monopoly in favour of the public interest;

2. For the development of strategic sectors by the Constitution of the Republic;

3. For the provision of public services following the Constitution of the Republic;

4. For the technological and industrial development of the national economy; and,

5. For the implementation of affirmative action or other legal initiatives in favour of the popular and solidarity economy. 
The establishment of restrictions on competition will proceed when specific, concrete and significant benefits are generated to satisfy the general interest, in the field or industry in which they are established, efficiency is increased, and benefits are generated in favour of consumers or users., that justify the application of the same. (Organic Law of Regulation and Control of Market Power, 2011)

Secondly, the theory of economic analysis of law includes the Coase Theorem - Transaction Costs ${ }^{2}$, which arguably allows reaching a socially beneficial agreement for the parties. According to the Coase Theorem, neither party can reach its optimum level when transaction costs are high. Therefore, it is necessary to issue a norm that regulates the market, as stated by Coase (1960) "since there are transaction costs, the legal rule is necessary to achieve economic efficiency". (Coase, 1960, cited by Beyer, 1992)

This, because regulation reduces transaction costs, and allows, among others things, to identify the owner (i), reduce the risk of losing the property (ii), since as explained by Coase (1960) "when transaction costs are zero (0) whatever the legal rule will reach the most economically efficient result ". (Coase, 1960, cited by Beyer, 1992)

For a better understanding, the types of transaction cost, on which this theory is based, are analyzed below:

a. Coordination costs. - the expenses involved in the transfer of the parties to reach an agreement, such as the transfer, determination of their identity, costs of delimiting the ownership of a property, protection costs, and others. (North, 1995. p .9)

b. Motivation and negotiation costs. - These are the costs that

2 The 1960 article The problem of Social Cost, 'The problem of social cost', is considered the most cited article in the economic literature of all times and countries. However, its central ideas were already explicit in the article The Nature of the Firm ("The nature of the company") of 1937, in which he explains that any price allocation system has a cost and that it is possible to make an economic analysis of the rules, the forms of organization and the payment methods 
prevent an agreement from being concluded: 1 . Specific assets understood as investments that have no value or are less valued outside the contract. Sometimes, in the transaction is necessary that one of the parties invests in something that has no value outside the agreement, with which the value is reduced or becomes null: and 2 . Asymmetry of the information, since the comprehensive information is ideal from an economic point of view, but the differences in information between the contractors prevent an agreement from being reached and make the agreements, not the most optimal. (North, 1996, p. 5)

c. Supervision costs and effectiveness of the agreement. - getting the agreements to be fulfilled is not free; it is necessary to tolerate that not all the commitments are fulfilled. (Raimondi, 1980, p. 612)

Thirdly, it is necessary to analyze the costs of property exclusion (iv), which occur when there are many rights holders, and all can prevent or exclude the use of the property. This produces deficient exploitation and supply of the resource. The economic, legal theory incorporates the analysis of the costs of exclusion and provision when there are public goods. They are those whose use by one individual does not reduce the possibility of use by another individual (non-rival), those who do not contribute to its production (not excludable) and cannot be excluded from use. (Fischer et al., 1987)

In this case, as was briefly analyzed, when it comes to public goods, the solution is that they are provided or administered by the State, or that exclusive property rights are defined, such as the case of concessions, or monopoly, and other forms of market distortion.

The article 604 of the Ecuadorian Civil Code defines public goods when specifying that: " (...) National goods whose use does not generally belong to the inhabitants are called state property or fiscal property." (Civil Code Ecuador, 2008) (Emphasis out of text). This demonstrates that the referred exclusion costs are fully incorporated into the Ecuadorian legal system by establishing the ownership of public goods as like they do NOT belong to the inhabitants. 
In two of the three briefly described considerations, it can be seen that when it comes to goods with several producers, the social benefit decreases. On the other hand, when it comes to public goods (non-rival and non-excludable), the theory shows that the State's administration or MONOPOLY is the most efficient forms of market.

\subsection{Intellectual Property in Ecuador}

Intellectual property must have a justification for granting exclusive exploitation rights, opposable and excludable to third parties since exclusive rights can be though as other forms of monopoly.

Monopolies, as a market distortion, have to be applied in a timely manner and as long as they do not affect the rights of individuals. There is a large number of regulations that control their formation, which will also be analyzed in this document.

The economic analysis of intellectual property helps legal experts and decision-makers in public policy to understand that structural and institutional factors have configured the right of this type of property. Economics allows analyzing individuals' possible behaviours, as the science that best values effects of regulations and intellectual property policies.

Intellectual property is a form of property that contains the concepts of regulation and protection of intangible assets that, in the end, will have a practical application, the intellectual creation.

In this case, we are faced with goods and services that can be created by various producers who will cause the following negative cost-benefit consequences: not covering the costs of production (i), loss of social welfare value (ii), and consequently, loss of incentives for creation, as it will be over or under-production (iii).

It is essential to mention that in the Ecuadorian case, the so-called coordination costs have been incurred (normative creation, the definition of the owner, property delimitation) so 
that the Constitution of the Republic of Ecuador (2008), and the Organic Code of the Social Knowledge-Economy, Creativity, and Innovation (2016), recognize and protect this type of less tangible property in order to generate production efficiency and incentives for all intellectual creation.

Thus, the article 322 of the Constitution of the Republic of Ecuador (2008), expressly recognizes intellectual property and prohibits the misappropriation of goods whose use is not excludable or available to individuals collectively (public goods), by manifesting: "Intellectual property is recognized following the conditions established by law. Any form of appropriation of collective knowledge is prohibited in science, technology, and ancestral knowledge. The appropriation of genetic resources containing biological diversity and agrobiodiversity is also prohibited.".

The same prohibition is established in its article 402, which states: "The granting of rights, including intellectual property rights, on derived or synthesized products, is prohibited and then it is obtained from the collective knowledge associated with national biodiversity." (CRE, 2008). The constitutional norm also recognizes intellectual property in its facet of copyright in its article 601: "The productions of talent or ingenuity are the property of their authors. This property will be governed by special laws." (CRE, 2008)

After constitutionally recognizing this type of property, the Ecuadorian legal system adopted the regulation and protection through its Law; the Intellectual Property Law. The current Organic Code of the Social Knowledge-Economy, Creativity, and Innovation repealed and replaced the Intellectual Property Law by generating an entire institutional framework for regulation and control of all intellectual inventions. It even created the Ecuadorian Institute of Intellectual Property, today the National Secretariat of Intellectual Rights.

The commonly called Código de Ingenios (Organic Code of the Social Knowledge-Economy, Creativity and Innovation, 2016), in its article 85 recognizes the protection of this type of property (i) as a tool to promote scientific, technological, 
artistic, and cultural development and to encourage innovation.

In other words, the Ecuadorian legislator is aware that, if this type of property is not protected, the intellectual creators, as will be seen later, will not have sufficient incentives to produce which will cause a lack of production eventually. In this way, we began to identify the foundation that the Ecuadorian legislator had to use in order to include this form of property, which is none other than the generation of incentives to produce intellectual goods.

There is a compendium of all the norms that regulate and control intellectual property rights in the Ingenious Code. Its article 85 establishes the protection scope of intellectual rights:

Art. 85.- Intellectual rights. - Intellectual rights are protected in all their forms, the same that will be acquired following the Constitution, the International Treaties of which Ecuador is a part and this Code. Intellectual rights comprise mainly intellectual property and traditional knowledge. Its regulation constitutes a tool for the adequate management of knowledge, to promote scientific, technological, artistic, and cultural development, as well as encourage innovation. Its acquisition and exercise, as well as its weighting with other rights, will ensure the effective enjoyment of fundamental rights and will contribute to adequate dissemination of knowledge for the benefit of the holders and society.

To the other existing modalities, this Code guarantees protection against unfair competition. (Organic Code of the Social Knowledge-Economy, Creativity and Innovation, 2016)

The article 88 of the same Code expressly establishes its purpose: "Intellectual property rights constitute a tool for the development of creative activity and social innovation. They contribute to technology transfer, access to knowledge and culture, innovation, and reduction of cognitive dependence." (Organic Code of the Social Knowledge-Economy, Creativity 
and Innovation, 2016). In this way, the parameters of the existence of standard goods are met, also generating the space for their exclusion from the public domain (rivalry and exclusion).

Art. 86.- Exception to the public domain. - Intellectual property rights constitute an exception to the public domain to encourage technological, scientific, and artistic development; and, they will respond to the function and social responsibility following the provisions of the Constitution and the Law. Intellectual property may be public, private, community, State, associative, cooperative, and mixed. (Organic Code of the Social Knowledge-Economy, Creativity and Innovation, 2016)

The rationale for protecting intellectual property is to seek the protection of intangible assets. One reason for this type of special protection towards intangible assets, against common property rights, is that social benefits between the two are different. The cost-benefit analysis is necessary for decisionmaking about public policy norms. Social costs and benefits must be considered against individuals.

Thus, the Ecuadorian constitution itself establishes in its article 85 that when a public policy affects collective rights (social benefits) must be reformulated:

Art. 85.- The formulation, execution, evaluation and control of public policies and public services that guarantee the rights recognized by the Constitution, will be regulated by the following provisions:

1. Public policies and the provision of public goods and services will be oriented to make a good living and all rights effective and will be formulated based on the principle of solidarity.

2. Without prejudice to the prevalence of the general interest over the private interest, when the effects of the execution of public policies or provision of public goods or services violate or threaten to violate constitutional 
rights, the policy or provision must be reformulated, or measures will be adopted alternatives that reconcile conflicting rights.

3. The State will guarantee the equitable and solidary distribution of the budget for the execution of public policies and the provision of public goods and services. In the formulation, execution, evaluation and control of public policies and public services, the participation of individuals, communities, peoples and nationalities will be guaranteed. (CRE, 2008)

The legislator understood that the regulation and protection of intellectual property rights is necessary in order to generate social benefits. The protection of other types of property, such as real property, is as much important as the protection of intellectual property since, without protection, there would be no incentives to produce.

Notwithstanding the preceding, it is necessary to make a small comparison between ownership of both types of property, in order to be sure that the protection of the real property is just as essential as the protection on intellectual property:

a. In both types of property (real and intellectual) there are incentives to innovate and produce, and therefore they both generate income from their use and exploitation.

b. If intangible assets are not protected their universal appropriation is an incentive not to produce since they are non-rival assets. It does not occur in real assets since they are rivals due to their straightforward delimitation.

c. Ownership of tangible assets can be delimited, whereas intangible assets' ownership is impossible or very expensive to establish. Then, regulation is necessary to protect them.

d. The costs of maintaining a property right are high, and in the case of intellectual property rights, their cost of protection is even higher.

The effect of fragmenting intangible property is to increase transaction costs and underutilizes the resource as there are multiple owners. This effect can be reduced 
if the transfer and collective contracting of intangible assets are allowed. Diversification of intangible property is not a problem.

e. Rent-seeking is higher in Intellectual Property. Therefore, it generates a more significant social benefit.

f. The cost of protection and enforcement of rights achieves better results (more effective) in intangible property rights.

\subsection{Copyright, As Part of Intellectual Property}

In the Ecuadorian legislation, according to article 89 of the Organic Code of the Social Knowledge-Economy, Creativity, and Innovation (2016): "Intellectual property rights mainly comprise copyright and related rights, industrial property and plant varieties."

The economic foundation for copyrights, patents, and trademarks is different like explained next:

a. Copyright and patents protect the interests of information or intellectual assets.

All informational or intellectual goods have two essential characteristics: non-rivalry and non-excludability. Regarding the first, as previously described, the use of the good does not diminish the possibilities of use by others; and, concerning the latter, the manufacturer cannot exclude from the use of a good those who do not pay for using it, in this case, the manufacturer cannot recover the investment of the elaboration (Mankiw, 1998, p. 140) Both characteristics cause people not to have benefits to produce, which leads to a severe problem of underproduction of informational goods. Therefore, the legislation grants rights that allow the producer to generate resources for producing and incentives by charging a favourable price. It leaves the producer to determine goods' high price and leads to limited access. 
1. Copyright is acquired by the mere fact of its creation.

In patents and trademarks, there is substantial government control. However, copyright registers do not get to determine the existence or not of a right since their ex-ante verification has a very high cost. That plus a large amount of already existing intellectual creation, and the low economic returns of most of the intellectual creations, make it impossible for authors to register their work.

2. Independent creation.

Who duplicates the work of an author by referring to the author does not infringe a right. Protection is given over that duplication. It is justified because the costs of preventing a duplication are high, whereas the benefits of duplication are low. It does not imply taking advantage of the work of others.

3. Protection of expression.

Copyright does not protect ideas but their form of expression since if all costs were protected, including the administrative ones, it would be so high that it would discourage protection.

4. Derivative works.

Authors may authorize the transformation of their work to others.

5. Terms.

Protection terms are established since the costs of creation and licensing increase over time. Copyrights should not be protected exclusively until the point where the creator recovers its creation costs.

6. Protection of non-authors.

Producers, interpreters, and unpublished works are also protected. 
On the other hand, the intellectual creation that allows the registration of patents has a high cost; in some cases, more significant than the economic benefit of exploitation. Therefore, it is not recommended that patents are required in the computer and business sectors -industrial property- since they have high costs of definition and protection. In this sense, it is advisable to protect intellectual creations through patents only in cases where the benefits of their exploitation are higher than the cost of creation.

b. Trademarks are goods, but they have no economic value. Their foundation is the power to transmit information to consumers. Consumers associate the quality of a specific manufacturer to a particular good. They avoid searching for another brand which produces incentives for manufacturers to have a certain quality in their production.

Brand dilution behaviours do not generate a risk of confusion or association since a renowned brand by itself makes its use rival and exclusive to others, and registration may be unnecessary.

\section{INCENTIVES TO CREATE INTELLECTUAL PROPERTY IN ECUADOR}

The Ecuadorian legal system has adopted regulation and protection, but the mere creation of the norm, and its costs, do not justify in isolation the creation of the legal system that protects this type of property. Therefore, incentives should be analyzed (Pindyck \& Rubinfeld, 2010, p. 6-7), that is, the prizes or positive benefits that potential creators of intellectual property may have to prefer to create it or not, and thus fully and correctly understand the adoption of intellectual property law.

There are several systems to promote innovation, but this document only analyzes the creation of intellectual property rights, adopted by the Ecuadorian regulatory system, and the free rewards system: 
1. The intellectual property rights refer to the legal right of exclusive use granted to the producer of a kind of artificial monopoly. It allows the expected benefits as incentives for intellectual creation to be higher than when competing in an unprotected market. The sale price is higher than the marginal cost $(\mathrm{P}>\mathrm{Cm})$, and the number of sales will be more significant since there will only be one producer. In this case, the monopoly is more efficient to generate incentives for production, compared to competitive market models.

With the creation and protection of intellectual property rights, a legal right of exclusive use is granted to the producer of an informational good (freeriding avoidance theory - ways to avoid the stowaway problem), with which, the sale price caused is higher than the marginal cost of creation.

2. Public rewards. - In this alternative, the State pays the author a contribution, making the property accessible to all. The State covers production costs and should also cover a reasonable profit to the producer to generate incentives for production. However, this system is not recommended because it causes a loss of efficiency since the price and marginal cost disappear in the negotiation or establishment of payment by the State, and the reward may be insufficient, exact, or excessive, generating risks for the State. And for the creator of the intellectual property itself. Furthermore, it would increase the costs of public administration in the transaction, including various quantifiable and considerable effects such as adverse selection problems.

By the above, it is observed that the public rewards system maintains important criticisms that make it a non-preferred alternative to intellectual property law, since, under the free reward system, the price should not be higher than the marginal cost (i), the profits of the producer will depend on whether there are benefits for the exploitation of intellectual property rights. Therefore, the State cannot establish a real and specific reward before 
knowing if the product will have economic returns (ii). Although the incentives to innovate are constant, the State will have the problem of establishing the optimal reward because, at the time of intellectual creation, it will not know the real demand for such creation (iii).

The article 86 of the Organic Code of the Social Knowledge-Economy, Creativity and Innovation (2016) takes the first scheme, the protection of intellectual property, by establishing that "Exception to the public domain. - Intellectual property rights constitute an exception to the public domain to encourage technological, scientific, and artistic; and, they will respond to the function and social responsibility under the provisions of the Constitution and the Law. Intellectual property may be public, private, community, State, associative, cooperative, and mixed." It can be seen that the Ecuadorian legal system preferred the protection of intellectual property rights over other types of incentives to create this type of property.

Intellectual property is a non-rival and non-excludable good because if it were rival and excludable, the creators would have no incentive to produce more books or to create new works. Therefore, in order not to resort to public provision, it has been preferred to grant an exclusive right of exploitation to a legitimate provider of that right. Intellectual property is a form of property like any other, but the intellectual property must enjoy a high level of protection because, without protection, there is no innovation.

However, exclusive rights do not solve the problem of incentives to produce by themselves. The economic theory proves this argument with the so-called Arrow Effect, when it analyzes a competitive inventor and a monopolist, and how incentives change once a patent is acquired. This theory is supported by K.J. Arrow (1962 Nobel Prize winner), who considers that the incentives for research are lower when the market power is high since the marginal cost of production is reduced, and by having inelastic demand, no new incentives for innovation are generated. (Arrow, 1962, cited by Restrepo Zea \& Rojas López, 2016) 
This theory concludes that the inventor in a competitive market has no incentive to continue creating, since being nonexcludable and non-rival goods, their creation and use does not generate the expected benefit to intellectual creation.

\section{CONCLUSIONS}

In Ecuador, intellectual property is recognized as a form of property right over intangible assets; and it is protected to generate incentives for its production.

The economic analysis of intellectual property represents one of the best ways to understand and explain why intellectual property rights have been created within the Ecuadorian legal system. The evidence developed shows that creators have sufficient incentives to produce intellectual goods in a market with protection.

In Ecuador, intellectual property rights generate an exclusive right of use and exploitation of property. In other words, they create towards authors a legal monopoly, which will allow the creator of the intellectual property to obtain the expected benefits.

In the absence of intellectual property protection, there are other types of incentives for creation that are less efficient. There are reasons to generate negative incentives for intellectual creation (Public reward, the problem of common goods).

In Ecuador, there is already in place a regulatory system that protects intellectual property. Nevertheless, it can be reformulated to cover social benefit generation. 


\section{REFERENCES}

Asamblea Nacional del Ecuador. Organic Code of the Social Knowledge-Economy, Creativity and Innovation. [Cod.]. (2016). R. O. 899, December 09, 2016.

Bentham, J. (1993). Critical Assessments, volume IV. New York: Routledge.

Beyer, H. (1992). Ronald H. Coase y su Contribución a la Teoría de la Economía y del Derecho. Estudios Públicos, 45, (pp. 1-22).

Coloma, G. (2003). La tragedia de los comunes y la tragedia de los anticomunes: una interpretación. Anales de la Academia Nacional de Ciencias Económicas, 48, (pp. 173-180).

Congreso Nacional del Ecuador. Civil Code. [Cod. 10]. (2005). R. O. 46 de 24 de junio de 2005.

Constitution of the Republic of Ecuador. [Const.]. (2008). 2nd Ed. CEP.

Cortés, A.B. (1973). Teoría Económica. Santiago, Chile: Talleres de Editorial Universitaria.

Duarte, T. \& Jiménez, R. E. (2007). Aproximación a la teoría del bienestar. Scientia et technica, 13(37).

Fischer, Dornbusch (1997). Economía. México: Mc Graw Hill.

Lloyd, W. F. (1833). Two Lectures on the Checks to Population. Oxford, England: Oxford University Press.

Mankiw, N. G. (1998). Principios de Economía (Primera ed.). Madrid: McGraw Hill.

North, D. (1995). Transaction Costs Through Time. St. Louis: Washington University, (p. 9).

North, D. (1996). Economics and Cognitive Science. St. Louis: Washington University, (p. 5). 
Pérez Gómez Tétrel, A. M. (2006). Análisis Económico del Derecho de Autor y Copyright, un Estudio del Equilibrio entre los Intereses Público y Privado. Revista La Propiedad Inmaterial, (10-11), (p. 3).

Pindyck, R. S. \& Rubinfeld, D. L. (2010). Mikroeconomia. España: Universidad Deusto.

Posner, R. (1998). El análisis económico del Derecho. México: Fondo de Cultura Económica.

Raimondi, C. (1980). Costos. Bs.As: Ediciones Contabilidad Moderna S.A.I.C., (p. 612).

Real Academia Española. (2014). Diccionario de la lengua española, 23rd ed. Retrieved from: https://dle.rae.es

Restrepo Zea, J. H. \& Rojas López, K.K. (2016). The genesis of Health Economics in Kenneth Arrow. Lecturas de Economía, (84), DOI: http://dx.doi.org/10.17533/ udea.le.n84a07

Received: 20/05/2019

Approved: 27/07/2020

Angel Fabián Albán de Saa: Head of litigation, Meythaler \& Zambrano Lawyers

Email: falban@lmzabogados.com

City: Quito

Country: Ecuador

Mary Mar Samaniego Alcívar: Deputy head of litigation at Meythaler \& Zambrano Lawyers.

Email: msamaniego@lmzabogados.com

City: Quito

Country: Ecuador 
